\title{
Static and Dynamic Liquidity of Polish Public Companies ${ }^{*}$
}

\author{
Artur Stefański \\ Poznan School of Banking, Poznan, Poland
}

\begin{abstract}
Three thesis were settled in the paper: the first thesis assumes that there exists a weak positive correlation between static and dynamic ratios of financial liquidity; the second thesis which complements the first one assumes that this correlation is stronger in the group of enterprises classified than the industry sector; and the third one-financial liquidity during the financial crisis would deteriorate. The analysis scope covers the period between 2005 and 2009, which is based on data collected from public companies listed on the Warsaw Stock Exchange on December 31, 2010. Financial data come from 128 business entities (55 from the industry sector, and 73 from trade and services sector). To verify the correlation between static and liquidity ratios, linear correlation between static and dynamic ratios was settled for the entire group and separate sectors. It can be observed a low level of correlation between static and dynamic liquidity ratios. The first thesis can be confirmed only when modified operating cash flows are used, but there are stronger dependences between variables in the industry sector than in trade and services, and generally liquidity ratios were not weaker during the financial crisis times.
\end{abstract}

Keywords: liquidity, cash flow, financial analysis

\section{Introduction}

While defining the basic goals of an enterprise, it is assumed most frequently that in a long-term perspective its activities are dominated by the maximization of the company's market value for its owners, whereas in a short-term perspective, the company aims at maintaining financial liquidity, i.e., the ability to meet its current liabilities on time.

The company's liquidity may be measured and estimated by considering:

- current assets and liabilities in a given moment—static measure of financial liquidity (e.g., current and quick ratios of financial liquidity);

- money flows generated by the company during the period under analysis—dynamic measure of financial liquidity (e.g., productivity ratios or cash sufficiency ratios).

The main objective of the paper herein is to analyze the correlation between static and dynamic liquidity ratios. Earlier research made in the area of such correlations prove that operating cash flows are related not to the current ratio, but rather to the quick ratio of liquidity, whereas simplified cash flows, calculated according to the formula: net financial result plus depreciation, and modified by the change of net working capital, are highly correlated with the ratios of both current and quick liquidity (Wertheim \& Robinson, 1993). Further analysis indicate that the generalization of any conclusions must be done carefully since the intensity of

\footnotetext{
* The author thanks Centrum Rozwoju Szkół Wyższych TEB Akademia Sp. z o.o., Poznań, Poland. Artur Stefański, Ph.D. in Economics, Banking and Financial Market, Poznan School of Banking.

Correspondence concerning this article should be addressed to Artur Stefański, al. Niepodległości 2, 61-874 Poznań, Poland. E-mail: artur.stefanski@wsb.poznan.pl.
} 
correlation among the parameters may differ significantly depending on the line of business (Lancaster, Stevens, \& Jeanings, 1999). It is worth emphasizing that in both studies the correlation analysis was provided by changing the values of financial indices on the one hand, and on the other hand, changing the amounts of financial entries. The correlation analysis of static and dynamic ratios for the Polish economy (for construction and trade sectors) was carried out by Maślanka (2008). It can be inferred from his research that between 1998-2004, the correlation between the ratios of current and quick liquidity, chosen productivity ratios and cash sufficiency ratios is positive in the construction sector (even though, there were observed some cases of negative correlation in the analyzed period within the subsequent years), instead of weak intensity (Maślanka, 2008). The research herein encompasses another group of business entities, including more recent financial data than the one quoted in the studies mentioned earlier, and is based on other financial ratios, sometimes slightly modified, than in earlier analysis. However, considering the results of earlier research, a hypothesis was made that there exist a weak positive correlation between static and dynamic indices used to measure financial liquidity of enterprises (H1). The thesis which complements this one assumes that correlation is stronger in the group of enterprises classified than the industry macro sector (H2).

There are a lot of factors, both external and internal, which may influence financial liquidity, therefore, it may be expected that in the period of worsening macroeconomic situation, the financial liquidity of particular enterprises may deteriorate as well. The analysis carried out for this research encompasses the period between 2004 and 2009, which including the financial crisis as well. In this case, a hypothesis was assumed that financial liquidity measured both by static and dynamic indices in the financial crisis between 2008-2009 would deteriorate (H3).

\section{The Analysis of Financial Liquidity of the Business Entities between 2005 and 2009 Listed on the Warsaw Stock Exchange on December 31, 2010}

\section{Sample Selection}

The analysis was made on the basis of financial results, within 2005-2009, of the public companies listed on the Warsaw Stock Exchange on December 31, 2010.

Only public limited companies were created according to the Polish commercial code. On December 31, 2010, the number of such entities equaled 301.

The data were used in the cross-section analysis. The companies listed on the Warsaw Stock Exchange may be classified into the following macro sectors: industry, trade and services as well as finances. The analysis included the companies belonging to the two of the above mentioned macro sectors. The finance macro sector was excluded.

The three most numerous sectors were selected in each macro sector. In the industry macro sector, nine sectors were occupied by the following industries: electromechanical, food, and metal. On the whole, there were 119 companies listed in the industry macro sector, whereas in the sectors which chosen for the analysis, there were 70 companies, which constitutes 59\%. In the trade and services macro sector, six sectors belonged to the companies operating in: construction, IT, and retail industries. The entire trade and services macro sector were consisted of 136 business entities, whereas in the sectors chosen for the analysis, there were 92 companies selected, constituting $68 \%$. Altogether, 162 business entities were chosen which accounted for $54 \%$ of the total number of the companies.

Furthermore, the companies are included in the data base of Notoria Serwis S.A. in December 2010, which 
did not provide unconsolidated reports (and these were unconsolidated reports which the analysis was focused on) as well as did not provide complete data for the period under analysis, or the company's results concerned the other balance sheet date on the last day of December, were excluded from the analysis. In the end, the analysis encompassed 55 companies included in the industry macro sector (i.e., $46 \%$ of the total number of companies in this sector) and 73 companies included in trade and services macro sector (namely, $54 \%$ of the total number of companies operating in this sector), i.e., in total 128 business entities (which constitute $43 \%$ of all public companies).

\section{Static Measures of Financial Liquidity}

A static measure of financial liquidity of a company is based on the ratio of current assets to liabilities in a given moment due to the information derived from the balance sheet. The most popular tools of the static analysis of liquidity are the indices defined as liquidity degrees. They are created by the ratio of particular entries of current assets and liabilities. Most frequently, three ratios (degrees) of liquidity are distinguished, namely, current liquidity ratio (III degree of financial liquidity), quick liquidity ratio (II degree of financial liquidity), and immediate liquidity ratio (I degree of liquidity). The ratios here above differ from each other in terms of assets liquidity included in the numerator. These assets may be divided according to the accounting and economic criterion (Waśniewski \& Skoczylas, 2002). According to the accounting criterion, there are distinguished the following liquidity degrees:

- III degree of liquidity is characteristic of reserves and short-term accruals;

- II degree of liquidity is typical of short-term liabilities;

- I degree of liquidity-short-term investments.

According to the economic criterion, there are distinguished the following liquidity degrees:

- assets of III degree of liquidity include e.g., goods and products in stock which are not marketed, reserves of materials for production in progress, advance payments for future deliveries, contested debts and past-due receivables;

- assets of II degree of liquidity include e.g., amounts due collected on due date, finished goods or products in stock for sale;

- assets of I degree of liquidity are short-term investments and this part of reserves of amounts due to which can be exchanged for cash immediately.

The application of the economic approach requires a wide variety of corrections of the amounts entered in the balance sheet, which is impossible in the sampling established for this research. Therefore, the accounting approach will be applied here. However, also in this case, there are some doubts as to the method of calculating particular indices. The numerator of ratios used in the paper will be calculated specifically according to the formula which has already presented, however, the category of current liabilities should be specified first in the denominator of particular ratios. Most frequently, it is identical to the category of short-term liabilities, however, there appear certain doubts whether it should be expanded by short-term reserves as well as accrued expenses and deferred revenues. When it comes to the first category, it will be excluded for the purpose of this paper, however, only due to lack of sufficiently precise financial data, because according to the author of the paper, short-term reserves should be included in the analysis as an integral part of current liabilities, certainly, if it is possible to obtain such data. In the case of accrued expenses and deferred revenues, either in the subject specific references or in the economic practice, there appear specific doubts if they should be included or not in 
the analysis and if each entry should be taken into account. For the purpose of this study, the following two approaches will be applied:

- the ratios of current (CR) and quick (QC) liquidity will be calculated without this category in the denominator, then the ratios will have a proper symbol (1);

- in the case of ratios with the symbol (2) accrued expenses and deferred revenues will be included in current liabilities.

The value of current and quick ratios of liquidity between 2005 and 2009 for the companies operating in industry, trade and services macro sectors listed on the Warsaw Stock Exchange on December 31, 2010, is illustrated in Table 1.

Table 1

The Value of Static Liquidity Ratios of the Companies Belonging to the Industry and Trade and Services Macro Sectors Between 2005 and 2009

\begin{tabular}{|c|c|c|c|c|c|c|c|c|c|c|}
\hline \multirow[b]{2}{*}{ Ratio } & \multirow[b]{2}{*}{ Year } & \multicolumn{9}{|c|}{ Sector } \\
\hline & & $\sum_{\Sigma}^{\mathbb{T}}$ & $\begin{array}{l}\text { व } \\
8 \\
0 \\
\end{array}$ & 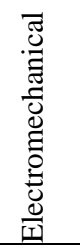 & 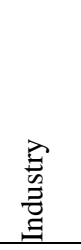 & 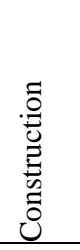 & 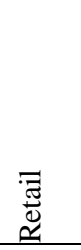 & 巨彑 & 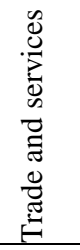 & $\stackrel{\vec{T}}{0}$ \\
\hline \multirow{6}{*}{ CR-1 } & 2005 & 1.82 & 1.29 & 2.19 & 1.80 & 1.30 & 1.55 & 1.87 & 1.56 & 1.66 \\
\hline & 2006 & 1.84 & 1.91 & 2.18 & 1.99 & 1.83 & 1.59 & 2.20 & 1.89 & 1.93 \\
\hline & 2007 & 2.37 & 1.56 & 2.77 & 2.27 & 2.20 & 2.54 & 2.36 & 2.35 & 2.31 \\
\hline & 2008 & 1.86 & 1.77 & 2.44 & 2.06 & 2.03 & 1.72 & 2.40 & 2.07 & 2.07 \\
\hline & 2009 & 1.88 & 1.83 & 2.58 & 2.13 & 2.11 & 1.78 & 2.33 & 2.09 & 2.11 \\
\hline & Average & 1.95 & 1.67 & 2.43 & 2.05 & 1.89 & 1.84 & 2.23 & 1.99 & 2.02 \\
\hline \multirow{6}{*}{ CR-2 } & 2005 & 1.77 & 1.18 & 2.13 & 1.73 & 1.23 & 1.54 & 1.80 & 1.51 & 1.60 \\
\hline & 2006 & 1.72 & 1.72 & 2.12 & 1.87 & 1.71 & 1.57 & 2.14 & 1.82 & 1.84 \\
\hline & 2007 & 2.31 & 1.43 & 2.74 & 2.20 & 2.06 & 2.40 & 2.24 & 2.21 & 2.21 \\
\hline & 2008 & 1.85 & 1.65 & 2.33 & 1.97 & 1.94 & 1.61 & 2.31 & 1.98 & 1.97 \\
\hline & 2009 & 1.86 & 1.75 & 2.49 & 2.07 & 1.94 & 1.73 & 2.22 & 1.98 & 2.02 \\
\hline & Average & 1.90 & 1.55 & 2.36 & 1.97 & 1.77 & 1.77 & 2.14 & 1.90 & 1.93 \\
\hline \multirow{6}{*}{ QR-1 } & 2005 & 1.25 & 0.79 & 1.46 & 1.19 & 1.13 & 0.85 & 1.59 & 1.21 & 1.20 \\
\hline & 2006 & 1.24 & 1.48 & 1.43 & 1.39 & 1.64 & 0.96 & 1.83 & 1.52 & 1.46 \\
\hline & 2007 & 1.81 & 1.16 & 1.96 & 1.66 & 1.91 & 1.87 & 2.01 & 1.93 & 1.82 \\
\hline & 2008 & 1.31 & 1.32 & 1.76 & 1.48 & 1.72 & 1.22 & 1.99 & 1.68 & 1.59 \\
\hline & 2009 & 1.22 & 1.37 & 1.81 & 1.49 & 1.83 & 1.14 & 1.95 & 1.68 & 1.60 \\
\hline & Average & 1.37 & 1.22 & 1.68 & 1.44 & 1.65 & 1.21 & 1.87 & 1.60 & 1.53 \\
\hline \multirow{6}{*}{ QR-2 } & 2005 & 1.22 & 0.71 & 1.42 & 1.14 & 1.08 & 0.84 & 1.53 & 1.17 & 1.16 \\
\hline & 2006 & 1.18 & 1.33 & 1.39 & 1.31 & 1.54 & 0.94 & 1.79 & 1.46 & 1.39 \\
\hline & 2007 & 1.77 & 1.06 & 1.94 & 1.62 & 1.80 & 1.76 & 1.91 & 1.83 & 1.74 \\
\hline & 2008 & 1.31 & 1.22 & 1.67 & 1.42 & 1.65 & 1.12 & 1.92 & 1.60 & 1.52 \\
\hline & 2009 & 1.21 & 1.32 & 1.75 & 1.45 & 1.68 & 1.09 & 1.85 & 1.58 & 1.52 \\
\hline & Average & 1.34 & 1.13 & 1.63 & 1.39 & 1.55 & 1.15 & 1.80 & 1.53 & 1.47 \\
\hline
\end{tabular}

Note. Source: Own elaboration. 
The analysis of static liquidity of the Polish public companies informs about their good financial liquidity both in terms of current liquidity and of the quick one. It is worth noticing that there is a slight difference between the ratios incorporating in the denominator, apart from short-term liabilities, also accrued expenses and the indices which do not include such items. Additionally, the ratios in both versions take the values considered as correct ones. Therefore, the further comment is limited only to the ratios due to symbol 1.

An average value CR-1 for the whole group of 128 companies oscillates between 1.66 and 2.31, whereas QR-1 between 1.20 and 1.82. The lowest value of indices was noted in 2005, whereas the highest one in 2007. The anticipated deterioration of static liquidity during the financial crisis did not take place. Moreover, the values of ratios between 2008 and 2009 were even higher than between 2005 and 2006.

Slightly higher values of liquidity ratios are observed in manufacturing companies rather than in trade and services companies, which is pretty predictable since it is connected with the commercial activity in particular sectors. CR-1 of manufacturing companies ranges between 1.80 and 2.27, and QR-1 between 1.19 and 1.66. However, in the case of the companies operating in trade and services sector, it varies between 1.56-2.35 and 1.21-1.93. An interesting point is that the difference on average sector values between CR and QR is greater for manufacturing companies, which proves that the reserves constitute a relatively higher part of current assets in this group of companies. While analyzing separately each sector included in the research, it can be observed that the highest current liquidity is typical of the enterprises operating in electro--mechanical sector (an average value of CR-1 equals 2.43), and the lowest one in the food sector (an average value of CR-1 equals 1.67). In terms of quick liquidity, the highest average values are noted in IT sector (1.87), and the lowest ones in retail (1.21). It is worth noticing that the biggest difference between current and quick liquidity is observed in electromechanical industry (0.75), and the lowest one in the construction sector (0.24), simultaneously, the construction sector registers the biggest changes in terms of the difference in an average value for five years.

Additionally, during the whole period under analysis, current liquidity ratio did not have the value lower than the recommended one in every sector (assuming that the recommended minimal value is 1.20). Quick ratios of financial liquidity, however, in 2005 were below the recommended value in food and retail sectors ( 0.79 and 0.85 respectively). In the case of retail sector, the situation repeated in 2006 when QR amounted to 0.96 .

\section{Dynamic Measures of Financial Liquidity}

Dynamic measures of financial liquidity of companies, in terms of their structure, take advantage of the information obtained from cash flows. Many specialists (Bowen, Burgstahler, \& Daley, 1986; Austin \& Bradbury, 1995; Mills \& Yamamura, 1998; Wędzki, 2003) tried to prove earlier that memorial and dynamic information provide different data, therefore, it is worth completing the classical analysis based on memorial information with the analysis of the data coming from cash flow accounts. The information included in cash flows allow for a much greater explanation of the financial situation, and in a much more practical and detailed way than the data included in the balance sheet, especially in terms of the structure of financing and financial liquidity (Waśniewski \& Skoczylas, 2002).

In the Polish subject-related references, the most popular division of the indices based on cash flows looks as following (Sierpińska \& Wędzki, 2007):

- cash sufficiency ratios;

- cash productivity ratios;

- cash flow structure ratios. 
Sometimes an attempt may be observed to classify the ratios on the basis of cash flows according to the criterion typical for the classical indices analysis, i.e., analytical area, then there arise a group of liquidity ratios, however, it should be stressed that the indices qualified to this group in a more popular division which was quoted earlier can be found in the group of cash sufficiency ratios, because this group of ratios, generally speaking, is used to measure the ability to generate financial resources by a company on the basis of its basic business activity in terms of capital servicing and financing investments.

The ratios, based on cash flows, which may help to measure liquidity are as follows:

- Ratio of operating cash sufficiency for paying liabilities (OS), which is calculated as ratio of cash obtained from operating activity to current liabilities (taking into account the comments included in the part on static analysis of liquidity in terms of current liabilities category, the ratio will be calculated in two versions and analogically assigned with the symbols 1 and 2 respectively);

- Ratio of modified operating cash sufficiency for liabilities payment (MS)—calculated as the ratio of the modified operating cash to current liabilities.

The modified balance of operating cash will be calculated as the balance of operating cash without the changes in working capital because the earlier research proved that the total amount of operating cash did not always provide the best data (Pauka \& Brycz, 2011).

It is worth adding that the structure of the indices of dynamic liquidity used in this paper indicates that they are mixed ratios. This information, however, comes from the balance sheet taken from the end of each period (for a given moment), because the goal of the ratios is to determine the ability to service the remaining payment of debts from the money generated from operating activity in the last year.

The values of operating cash sufficiency ratios and modified operating cash ratios for the payment of current liabilities between 2005 and 2009 for the companies operating in industry, trade and services macro sector, listed on the Warsaw Stock Exchange on December 31, 2010, are illustrated in Table 2.

Similarly to static liquidity, the value of operating cash sufficiency ratio and modified operating cash ratio in dynamic liquidity calculated according to symbols 1 and 2 differ slightly. Therefore, the remaining comments will be limited only to the ratios calculated according to symbol 1 .

Generally speaking, average values of dynamic liquidity ratios in the entire group of analyzed companies have a positive value. The sufficiency of operating cash ranges from 0.03 in 2007 to 0.31 in 2009, whereas the sufficiency of modified operating cash to pay short-term liabilities from 0.21 in 2008 to 0.39 in 2006. The differences, frankly speaking quite big, between these ratios are the result of the change of working capital balance. The fact that the value of the modified ratio is higher means the changes of working capital negatively influence operating flows, which means the companies freeze a part of their cash in working capital.

It is worth noticing that the ratio based on operating cash flows does not confirm the hypothesis made at the beginning that the lowest values would be observed in 2008-2009, whereas the ratio of operating cash flows modified by working capital to short-term liabilities in 2005-2007 maintains at a similar level, in order to fall dramatically in 2008 to the lowest level in the analyzed period, and in 2009 to grow again to the level achieved in 2005. Such ratio fluctuations allow for formulating the thesis that dynamic ratios of liquidity which do not take into account the changes in working capital confirm that financial liquidity of companies during financial crises deteriorates, additionally, it is compatible with the results of earlier research proving that operating flows do not always provide the most informative data. 
Table 2

The Values of Operating Cash Sufficiency Ratios and Modified Operating Cash Ratios to Pay the Liabilities of Industry and Trade and Services Macro Sectors Between 2005 and 2009

\begin{tabular}{|c|c|c|c|c|c|c|c|c|c|c|}
\hline \multirow[b]{2}{*}{ Ratio } & \multirow[b]{2}{*}{ Year } & \multicolumn{9}{|c|}{ Sector } \\
\hline & & 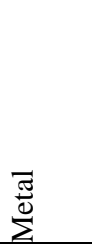 & $\begin{array}{l}\text { T. } \\
8 \\
\end{array}$ & 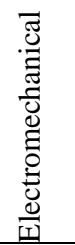 & 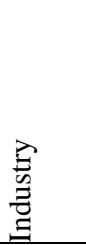 & $\begin{array}{l}.0 \\
.0 \\
0 \\
0 \\
0 \\
0 \\
0\end{array}$ & 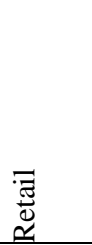 & $E$ & 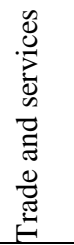 & $\underbrace{\overline{0}}_{-\pi}$ \\
\hline \multirow{6}{*}{ OS-1 } & 2005 & 0.27 & 0.17 & 0.36 & 0.27 & 0.03 & 0.21 & 0.30 & 0.17 & 0.22 \\
\hline & 2006 & 0.31 & 0.20 & 0.25 & 0.25 & 0.02 & 0.13 & 0.43 & 0.19 & 0.22 \\
\hline & 2007 & -0.60 & 0.13 & 0.25 & -0.05 & -0.04 & 0.14 & 0.18 & 0.08 & 0.03 \\
\hline & 2008 & 0.29 & 0.00 & 0.33 & 0.21 & -0.02 & 0.18 & 0.32 & 0.15 & 0.18 \\
\hline & 2009 & 0.35 & 0.21 & 0.52 & 0.37 & 0.25 & 0.18 & 0.34 & 0.26 & 0.31 \\
\hline & Average & 0.13 & 0.14 & 0.34 & 0.21 & 0.05 & 0.17 & 0.32 & 0.17 & 0.19 \\
\hline \multirow{6}{*}{ OS-2 } & 2005 & 0.26 & 0.16 & 0.35 & 0.26 & 0.04 & 0.21 & 0.29 & 0.17 & 0.21 \\
\hline & 2006 & 0.28 & 0.17 & 0.25 & 0.24 & 0.02 & 0.13 & 0.42 & 0.19 & 0.21 \\
\hline & 2007 & -0.61 & 0.12 & 0.24 & -0.06 & -0.05 & 0.14 & 0.18 & 0.08 & 0.02 \\
\hline & 2008 & 0.29 & 0.00 & 0.30 & 0.20 & -0.03 & 0.16 & 0.31 & 0.14 & 0.17 \\
\hline & 2009 & 0.35 & 0.20 & 0.50 & 0.36 & 0.23 & 0.16 & 0.32 & 0.24 & 0.29 \\
\hline & Average & 0.12 & 0.13 & 0.33 & 0.20 & 0.04 & 0.16 & 0.30 & 0.16 & 0.18 \\
\hline \multirow{6}{*}{ MS-1 } & 2005 & 0.39 & 0.23 & 0.61 & 0.42 & 0.08 & 0.22 & 0.49 & 0.26 & 0.33 \\
\hline & 2006 & 0.70 & 0.32 & 0.40 & 0.47 & 0.29 & 0.24 & 0.44 & 0.32 & 0.39 \\
\hline & 2007 & 0.60 & 0.13 & 0.56 & 0.44 & 0.22 & 0.38 & 0.28 & 0.28 & 0.35 \\
\hline & 2008 & 0.21 & 0.12 & 0.48 & 0.28 & 0.15 & -0.02 & 0.31 & 0.16 & 0.21 \\
\hline & 2009 & 0.34 & 0.30 & 0.51 & 0.39 & 0.28 & 0.31 & 0.29 & 0.29 & 0.33 \\
\hline & Average & 0.45 & 0.22 & 0.51 & 0.40 & 0.20 & 0.22 & 0.36 & 0.26 & 0.32 \\
\hline \multirow{6}{*}{ MS-2 } & 2005 & 0.37 & 0.19 & 0.60 & 0.40 & 0.08 & 0.21 & 0.47 & 0.25 & 0.32 \\
\hline & 2006 & 0.65 & 0.28 & 0.40 & 0.44 & 0.23 & 0.23 & 0.43 & 0.30 & 0.36 \\
\hline & 2007 & 0.59 & 0.12 & 0.56 & 0.43 & 0.21 & 0.33 & 0.27 & 0.26 & 0.34 \\
\hline & 2008 & 0.22 & 0.11 & 0.41 & 0.26 & 0.14 & -0.04 & 0.29 & 0.14 & 0.19 \\
\hline & 2009 & 0.33 & 0.30 & 0.51 & 0.39 & 0.25 & 0.29 & 0.27 & 0.27 & 0.32 \\
\hline & Average & 0.43 & 0.20 & 0.49 & 0.38 & 0.18 & 0.20 & 0.35 & 0.24 & 0.30 \\
\hline
\end{tabular}

Note. Source: Own elaboration.

Average values of operating cash sufficiency ratios and modified operating cash ratios in particular macro sectors in the entire period under analysis have positive values, and similarly to static ratios are higher in industry macro sector, respectively, 0.21 and 0.40 as well as 0.17 and 0.26 . Simultaneously, it should be stressed that in both cases, modified operating cash ratio has a higher value, and the difference between the ratios is higher in the group of manufacturing companies, which means that the share of working capital in the process of generating operating cash is higher in manufacturing companies, i.e., operating cash is influenced more by the changes in operating capital in this group of companies.

If each sector is analyzed separately, the highest values of dynamic liquidity ratios are noticed in the enterprises operating in the electromechanical industry, and the lowest in the construction sector. It is worth mentioning that the difference between average values of both analyzed ratios of dynamic liquidity is significantly the highest in the metal sector, whereas the lowest in the IT sector, and there is a slight difference in the retail sector.

Another interesting point to observe is that in the industry macro sector in 2007, average values of dynamic ratios were negative. It was the result of extremely low ratios achieved in that year by the enterprises 
operating in the metal sector (ratios of operating cash sufficiency and modified operating cash ratios amounted to -0.60 and -0.67 respectively). Apart from this sector, negative values of dynamic ratios in two subsequent years 2007 and 2008, were recorded in the construction industry, however, the values of ratios were not weaker than -0.05 .

\section{Correlation Between Static and Dynamic Indices of Liquidity}

Due to the fact that the values of dynamic and static ratios of financial liquidity are calculated according to symbol 1 and 2, which differ slightly, the correlation analysis was narrowed to the ratios based on symbol 1 only. The values of person linear correlation coefficients between static and dynamic ratios were settled for the entire group (i.e., 128 entities), for the group of manufacturing companies, separately for the companies of trade and services macro sector and separately for each of six sectors as well. The calculations were made for the following years between 2005 and 2009, and for the entire analyzed period put together on the basis of annual data. The summary of the calculations is included in Table 3.

Table 3

The Values of Correlation Coefficients Between Static and Dynamic Ratios

\begin{tabular}{|c|c|c|c|c|c|c|}
\hline \multirow{2}{*}{ Sector } & \multicolumn{6}{|l|}{ Year } \\
\hline & 2005 & 2006 & 2007 & 2008 & 2009 & Together \\
\hline \multicolumn{7}{|l|}{ CR versus OS } \\
\hline Metal & 0.46 & 0.56 & -0.85 & 0.31 & 0.08 & -0.52 \\
\hline Food & -0.05 & -0.02 & -0.40 & -0.84 & -0.15 & -0.43 \\
\hline Electromechanical & 0.31 & 0.66 & 0.24 & 0.55 & 0.76 & 0.48 \\
\hline Industry & 0.37 & 0.42 & -0.60 & -0.05 & 0.35 & -0.23 \\
\hline Construction & 0.20 & 0.04 & 0.06 & -0.72 & -0.02 & -0.20 \\
\hline Retail & 0.79 & -0.30 & 0.58 & 0.74 & 0.38 & 0.47 \\
\hline IT & -0.02 & 0.14 & 0.21 & 0.10 & 0.04 & 0.09 \\
\hline Trade and services & 0.25 & 0.10 & 0.26 & -0.21 & 0.13 & 0.05 \\
\hline Total & 0.33 & 0.22 & -0.36 & -0.14 & 0.24 & -0.12 \\
\hline \multicolumn{7}{|l|}{ CR versus $\mathrm{MS}$} \\
\hline Metal & 0.84 & 0.09 & 0.69 & 0.27 & -0.14 & 0.31 \\
\hline Food & 0.01 & 0.71 & -0.01 & 0.05 & -0.19 & 0.09 \\
\hline Electromechanical & 0.66 & 0.64 & 0.64 & 0.49 & 0.78 & 0.63 \\
\hline Industry & 0.63 & 0.37 & 0.62 & 0.31 & 0.15 & 0.39 \\
\hline Construction & 0.22 & 0.11 & 0.25 & -0.38 & 0.04 & 0.09 \\
\hline Retail & 0.74 & 0.31 & 0.41 & 0.56 & 0.37 & 0.44 \\
\hline IT & 0.64 & 0.25 & 0.53 & 0.02 & 0.07 & 0.20 \\
\hline Trade and services & 0.57 & 0.20 & 0.39 & 0.12 & 0.16 & 0.25 \\
\hline Total & 0.61 & 0.28 & 0.50 & 0.22 & 0.15 & 0.32 \\
\hline \multicolumn{7}{|l|}{ QR versus OS } \\
\hline Metal & 0.41 & 0.35 & -0.88 & 0.20 & 0.16 & -0.59 \\
\hline Food & 0.27 & 0.11 & -0.40 & -0.82 & -0.15 & -0.39 \\
\hline Electromechanical & 0.29 & 0.68 & 0.21 & 0.41 & 0.67 & 0.41 \\
\hline Industry & 0.36 & 0.32 & -0.69 & -0.18 & 0.25 & -0.32 \\
\hline Construction & 0.22 & 0.06 & 0.09 & -0.60 & 0.01 & -0.13 \\
\hline Retail & 0.42 & -0.01 & 0.63 & 0.74 & 0.39 & 0.49 \\
\hline IT & -0.13 & 0.17 & 0.19 & -0.03 & 0.02 & 0.05 \\
\hline Trade and services & 0.12 & 0.13 & 0.28 & -0.16 & 0.13 & 0.07 \\
\hline Total & 0.23 & 0.19 & -0.38 & -0.16 & 0.18 & -0.16 \\
\hline
\end{tabular}


(Table 3 continued)

\begin{tabular}{|c|c|c|c|c|c|c|}
\hline \multirow{2}{*}{ Sector } & \multicolumn{6}{|l|}{ Year } \\
\hline & 2005 & 2006 & 2007 & 2008 & 2009 & Together \\
\hline \multicolumn{7}{|l|}{ CR versus MS } \\
\hline Metal & 0.85 & 0.00 & 0.66 & 0.14 & 0.02 & 0.29 \\
\hline Food & 0.53 & 0.75 & -0.08 & 0.00 & -0.19 & 0.11 \\
\hline Electromechanical & 0.65 & 0.70 & 0.53 & 0.42 & 0.78 & 0.58 \\
\hline Industry & 0.69 & 0.36 & 0.53 & 0.19 & 0.12 & 0.33 \\
\hline Construction & 0.23 & 0.14 & 0.25 & -0.28 & 0.02 & 0.12 \\
\hline Retail & 0.35 & 0.24 & 0.40 & 0.53 & 0.25 & 0.36 \\
\hline IT & 0.60 & 0.20 & 0.53 & 0.14 & 0.01 & 0.20 \\
\hline Trade and services & 0.47 & 0.19 & 0.37 & 0.21 & 0.08 & 0.23 \\
\hline Total & 0.57 & 0.25 & 0.43 & 0.19 & 0.10 & 0.27 \\
\hline
\end{tabular}

Note. Source: Own elaboration.

The calculations presented in Table 3 prove a low correlation between static and dynamic ratios describing financial liquidity of enterprises. It is worth emphasizing that while taking into account the results of the entire group, a positive correlation between the variables is observed when modified by working capital operating cash is applied. However, if the analysis takes into account total operating flows-they are negatively correlated with both current liquidity ratios and the quick one. Therefore, the hypothesis concerning a weak positive correlation between static and dynamic ratios of financial liquidity may be confirmed only in the case of modified flows.

Much more visible intensity of correlation between static and dynamic liquidity ratios is observed if the analysis is made in the macro sector dimension. It should be stressed in each analyzed relation between the ratios that in the case of the industry sector, the correlation is positive. In the latter case of the analyzed macro sectors, the directions of correlation confirm the observations for the entire analyzed group. Generally speaking, this intensity of interdependencies between the ratios is higher in the industry macro sector, even though still remains weak.

Even stronger correlations can be observed while disaggregating the group. It is noticed in three sectors: electromechanical, retail, and IT. The dependences between static and dynamic ratios of liquidity are positive irrespectively of the pair of ratios which were applied. Additionally, in the case of electromechanical sector, the thesis may be made that the correlation between static and dynamic ratios of liquidity is characterized by medium intensity (the values of correlation coefficient amount to between 0.41 and 0.63 are higher if quick ratio of liquidity is applied and operating cash is modified by the change of working capital). In the case of the remaining sectors, their interdependence is weak.

If the analysis is done separately for each year, then the intensity and direction of interdependences are much more diversified. Only the ratios in the electromechanical sector are stable in terms of the direction-in each of the analyzed period, it is a positive correlation, and its intensity ranges between 0.21 and 0.78 . Two other sectors: retail and IT are highly stable in terms of the direction of interdependences between the variables. In 4 of 5 analyzed years, these correlations are positive, what is more, negative correlations are observed only in one of the periods, and only when the analysis takes all operating flows into consideration. If modified flows are to be applied, then the direction of correlation remains unchangeably positive in both sectors.

It is surprising that the highest negative correlation was observed in 2007 in the metal sector and amounted to -0.88 , whereas the highest positive correlation was noticed in 2005 in the metal industry and equaled to 0.85 . The metal sector can be characterized by the highest changeability of correlation ratios during the years. 


\section{Conclusions}

Summing up the research, it can be observed that generally low level of correlation between static and dynamic liquidity ratios may prove that the ratios most often include different data about enterprises. So, a conclusion can be drawn that, for the proper evaluation of the financial situation of a given business entity in terms of its liquidity, it is often necessary to provide simultaneously the analysis of a balance sheet and cash flows. At the same time, it is worth noticing that the highest value of the correlation ratios was observed when modified flows by the change of working capital operating cash flows were used. If the conclusions are based only on the analysis of modified operating cash, then the hypothesis (H1) of a weak positive correlation between static and dynamic ratios will be confirmed. If the analysis is based on total operating flows, then this part of the hypothesis cannot be confirmed.

However, irrespectively of the applied cash flows, their intensity of correlation with static indices of financial liquidity is higher in the industry sector, which allows to confirm the second thesis made at the beginning.

The third of the hypothesis that financial liquidity measured both by static and dynamic ratios during the financial crisis would deteriorate in most ratios applied in the analysis was not confirmed. The only exception is the dynamic ratio of the sufficiency of modified operating cash flow for paying current liabilities. In this case, in 2008, a sudden drop of index values was observed versus its level observed in the subsequent years.

\section{References}

Austin, L., \& Bradbury, M. (1995). The accuracy of cash flow estimation procedures. Accounting and Finance, 1, 73-86.

Bowen, R., Burgstahler, D., \& Daley, L. (1986). The incremental information content of accrual versus cash flows. Accounting Review, 4, 723-748.

Lancaster, C., Stevens, J. L., \& Jeanings, J. A. (1999). Corporate liquidity and the significance of earning versus cash flow: An examinations of industry effects. Journal of Applied Business Research, 3, 37-46.

Maślanka, T. (2008). Przepływy pieniężne w zarzqdzaniu finansami przedsiębiorstw. Warszawa: C.H. Beck.

Mills, J. R., \& Yamamura, J. H. (1998). The power of cash flow ratios. Journal of Accountancy, 186(4), 53-61.

Pauka, M., \& Brycz, B. (2011). Information value of cash flow statement in crisis period-Empirical research. Prace Naukowe Uniwersytetu Ekonomicznego we Wroctawiu, 158, 274-289.

Sierpińska, M., \& Wędzki, D. (2007). Zarzq̨dzanie plynnościq finansowa $w$ przedsiębiorstwie. Warszawa: Wydawnictwo Naukowe PWN.

Waśniewski, T., \& Skoczylas, W. (2002). Teoria i praktyka analizy finansowej w przedsiębiorstwie. Warszawa: Fundacja Rozwoju Rachunkowości.

Wędzki, D. (2003). Statystyczna weryfikacja istotności przepływów pieniężnych. Zeszyty Teoretyczne Rachunkowości, 15, 103-119.

Wertheim, P., \& Robinson, M. A. (1991). Earning versus cash flow: The information provided about changes in company liquidity. Journal of Applied Business Research, 4, 65-75. 